\title{
PERCIEVED EFFECTS OF INFORMATION AND COMMUNICATION TECHNOLOGIES IN AGRICULTURAL EXTENSION SERVICE DELIVERY IN OWERRI WEST LGA OF IMO STATE, NIGERIA
}

\author{
J.C. Nwaiwu ${ }^{1}$ and M.N. Okeke ${ }^{2}$ \\ ${ }^{1}$ Department of Agricultural Economics, Extension and Rural Development, Imo State \\ University, Owerri \\ ${ }^{2}$ Department of Agricultural Economics, Extension and Rural Development, Chukwuemeka \\ Odumegwu Ojukwu University (COOU) Igbariam Campus, Anambra State, Nigeria
}

Corresponding author: juanhyginus04@yahoo.com 08039511468

\begin{abstract}
ICTs devices have great potential for use in agricultural extension delivery and are increasingly being used without corresponding research into their optimal use. The study analyzed the effects of Information and Communication Technologies (ICTs) in agricultural extension in Owerri West Local Government Area of Imo State, Nigeria. Specifically, the study described the socioeconomic characteristics of farmers, identified the level of awareness of farmers on ICTs devices, described the type of ICTs devices available for use in agricultural extension delivery, examined the effectiveness of ICTs devices and identified the barriers farmers face in the use of ICT devices. Sample size comprised fifty (50) farming households selected using simple random sampling techniques. Structured questionnaire was the main tool for data collection. Data collected were analyzed using descriptive statistical tools and multiple regression analysis. Mean age was 45 years. Majority (74.0\%) were male and about $76.0 \%$ were married with a mean household size of 6 persons. Mean farming experience was 20 years, while about $78.0 \%$ were members of farmers' associations. Average monthly farm income was N49, 500.00. Greater proportions $(58.0 \%)$ did not have access to extension agents. Sizable proportions (82.00\%) were highly aware of various ICT tools used in agricultural extension.. Estimated multiple regression models revealed that the socio-economic characteristics of the farmers have a significant influence on their level of effectiveness in use of ICTs devices. Farmers identified high cost of ICTs devices (94.00\%) and inadequate power supply (86.00\%) as their barriers in the use of ICTs devices in the area. It was recommended that seminars and workshops should be organized for farmers on the use of various ICTs devices as this would enhance their use of ICT and promote effective agricultural delivery.
\end{abstract}

Keywords: Agricultural extension, Information and Communication Technology), Extension services, Imo State.

https://dx.doi.org/10.4314/jafs.v17i1.8

Journal of the Faculty of Agriculture and Veterinary Medicine, Imo State University Owerri website: www ajol.info 


\section{INTRODUCTION}

Most African economies are dominated by agriculture which contributes about $17 \%$ to the gross domestic product (GPD), 40\% of exports, employment creation and has the potential to reduce poverty (Wikipedia, 2009). The agricultural sector has been described as the engine for economic growth and improved livelihoods in Africa (World Bank 2000C). The majority of the farmers/producers in sub-Sahara Africa lives in rural areas and depends directly or indirectly on Agricultures. Despite the great potential for agricultural production in Africa about $73 \%$ of the poor people living in rural area subsist in less than a dollar a day. About 200 million people of the worlds hungry people are found in the continent, (millennium Development goals MDGs Technical support center 2004) and available statistic suggest that about one third of Africa has the highest proportion of people living in extreme poverty in the world. Available statistic suggests that about $26 \%$ of Africa population is malnourished. There has been under investment in the rural areas, inadequate access to market and unfair market conditions.

Global attention is back to agriculture due to the price increase of goods in recent years, resulting partly from long-standing negligence on diffusion of appropriate technology that stagnated production in the face of a rising population. Increasing population is a major challenge facing agriculture nowadays. Smallholder farmers which dominate the landscape of developing world need to improve farming through acquiring adequate knowledge and information. Agricultural extension services provide critical access to the knowledge, information and technology that farmers require to improve the productivity and thus improve the quality of their lives and livelihoods. It is hence crucial to provide farmers with the knowledge and information in a quality and timely way. Although some ground breaking tools like the telecasters can serve as major catalysts for information, knowledge and development opportunities, the access for farmers in remote villages is restricted due to lack of infrastructure.

Information communication technology (ICT) is growing rapidly even in the remote areas. The unprecedented speed of adoption of the computers, mobile phones, radios and television technology etc. has raised the general expectations about its potential contributions to spread of innovative farming technology, as well as farmers' knowledge and awareness of other relevant knowledge and information. What is the impact of information communication technology (ICT) on agricultural extension services delivery? What is the impact on farmers' attitudes to new agricultural technology in the future? These are important questions that have not yet been fully answered. Although there have been some evaluation studies of the impact of ICT, the normal assessment method is often subject to serious selection bias. In addition to the normal question regarding the impact on the speed, quality and volume of service delivery, it is also essential to understand the influence of the experience on farmers knowledge of agricultural technology and their attitudes towards future adoption of new technology. 
The traditional means and channels used by extension agents in disseminating information in this country are usually expensive and limited in coverage (Nwachukwu, 2003). Some of these inefficient channels are based on face to face visits which are usually limited to farmers who are within the reach of the extension agents while those in poor terrains are usually excluded.

Based on this, farmers complain of lack of knowledge of improved agricultural technologies and hence stick to their old and traditional methods, resulting to low yield and low productivity. But with the presence and availability of ICT devices, a lot and in fact almost all extension agents use ICT devices for information dissemination such as radio, TV, phone call, text message, emails, etc which has wide coverage and expected to reach even the farmers living in the remote areas with no access road. Looking at this, it is now expected that there will be tremendous increase in adoption of improved technologies and hence bumper harvest for farmers.

It is against this backdrop that this research looked at the effect of information communication technology in agricultural extension service delivery in Owerri West L.G.A of Imo State, Nigeria.

\section{Hypothesis of the Study}

The null hypothesis of the study is the socio-economic characteristics of farmers do not have significant influence on their effectiveness in the use of Information Communication Technology devices.

\section{MATERIALS AND METHODS}

Imo State is the study area and it is located between latitude $4^{0} 45^{\prime}$ and $7^{0} 15^{\prime}$ north of the equator and longitudes $6^{0} 50^{\prime}$ and $7^{0} 25^{\prime}$ east of the Greenwich Meridian (www.imostate.gov.ng). Owerri West is one of the Local Government Areas in Owerri Agricultural Zone of Imo State. It comprises of fifteen communities namely; Umuguma, Avu, Okuku, Ohii, Oforola, Obinze, Nekede, Ihiagwa, Eziobodo, Okolochi, Emeabiam, Irete, Orogwe, Amakohia and degwu. Owerri West Local Government Area covers an area of about $295 \mathrm{~km}^{2}$ and a population of 99,265 with many subsistence farmers; (NPC, 2006). Simple random sampling technique was used in the selection of 50 contact farmers for the study. Data were collected through the use of a set of structured questionnaire. This was supplemented with oral interview in places where the respondents could neither read nor write.

Descriptive statistics namely, frequency distribution, mean, mean score, merit scale, multiple regression and rating were used to analyze the data collected.

The implicit model of the multiple regression is given as follows:

$Y_{1}=f\left(x_{1}, x_{2}, x_{3}, x_{4}, x_{5}, x_{6}, x_{7}, x_{8}+e\right)$

Where $\mathrm{Y}_{1}=$ impact of the use of ICT [Three point likert -type scale measurement: High $=3$, moderately $=2$, low $=1]$ 
Journal of Agriculture and Food Sciences

$\mathrm{X}_{1}=$ age $($ years $)$

$\mathrm{X}_{2}=$ education level (years)

$\mathrm{X}_{3}=$ farming experience (years)

$\mathrm{X}_{4}=$ Household size (Numbers of persons)

$\mathrm{X}_{5}=$ farm income $(\AA)$

$\mathrm{X}_{6}=$ membership of farm association (member 1 other wise 0 )

$\mathrm{X}_{7}=$ access to extension agents (access 1 no access 0 )

$\mathrm{X}_{8}=$ Marital Status

$\mathrm{e}=$ error terms

\section{RESULTS AND DISCUSSION}

\section{Socio-economic Characteristics of the Farmers}

The mean age was 45.00 years. The farmers are still relatively in their middle age, hence can increase their access to ICTs devices in agricultural production. Greater proportions $(74.00 \%)$ of the farmers were males while about $26.00 \%$ were females. The finding implies that both sex is involved in agricultural production but males were dominant than females in the area.

The mean years of education were 12.00years. The finding implies that approximately $94.00 \%$ of the farmers had trainings in formal educational institutions which no doubt increases their literacy levels. It is also expected that the higher level of education will contribute significantly to understanding of the importance of ICTs used in agricultural extension delivery as well as enhance fast adoption of agricultural innovation by the farmers.

Greater proportions $(76.00 \%)$ of the farmers were married; approximately $18.00 \%$ were single while about $6.00 \%$ were widowed. The implication of the finding is that agricultural production in the area is an enterprise of married individuals, who are seen to be responsible according to societal standards (Bawa and Ani, 2014). The average farming experience was 20years showing that the farmers were very much experienced and could adapt to changes as regards innovation dissemination.

The mean household size was 6.0 persons. The implication of the findings is that farmers in the area had sizeable household size which is expected to increase their access to farm labour. This findings support the result of Abdoulay et al., (2015) who reported that large household size is a proxy to labour availability and reduce the cost of hired labour.

The result of the farmers' distribution based on membership of farmer's association is $78.00 \%$. The finding implies that majority of farmers had access to credit facilities through the cooperative society to which they belonged, to enhance their agricultural production. 
A greater proportion $(58.00 \%)$ of the farmers had no access to extension agents while the remaining proportion $(42.00 \%)$ had access to extension agents. Since farmers in the study area were poorly visited by extension agents to ascertain their farming problems, know where they need assistance and pass across to them any new/improved practices through ICTs devices, this situation may have a negative effect on their agricultural production in the area.

The mean annual farm income was $\mathrm{N} 49,500.00$. It is also expected that farmers with high farm income would be able to purchase relevant ICTs devices to help them keep abreast of modern technology, information and adopt agricultural innovation faster than their counterpart with lower farm income in the area.

\section{Farmers Level of Awareness on ICTs devices used by Extension Agents}

The result of the farmers' distribution based on level of awareness on ICTs devices used by extension agents in the area is presented in Table 2. It shows that greater proportion $(82.00 \%)$ of the farmers were highly aware of various ICTs devices used by extension agents in the dissemination of agricultural information and innovation in the area. The finding shares view with the study of Ogunremi (2013) who reported that if farmers are aware and have access to ICTs devices it will boast the understanding and adoption of agricultural innovation passed across to them through extension agents.

\section{Various ICTs Devices Used in Agricultural Extension Delivery}

The result of the several ICTs devices used in agricultural extension delivery is shown in Table 3. All the farmers (100.00\%) reported that they got their agricultural information from radio through the extension agents in the area. The study of Salau and Saingbe (2008) asserted that most of rural farmers have been reported to have huge access to radio than any other ICTs devices. Several advantages are linked to the use of radio; personal interaction in terms of contribution during live radio program, language understanding, literacy clarity, avoidance of time wasting and mass outreach (Olaniyi, 2013).

The finding also reveals that approximately $96.00 \%, 86.00 \%, 80.00 \%$ and $76.00 \%$ of the farmers identified telephones (GSM), posters, printer and digital camera respectively as the devices extension agents used in the dissemination of agricultural information and innovation in the area. The study of Dauda et al (2009) asserted that the use of telephone might be attributed to the increasing growth in the proliferation and use of cell phones in Nigeria- with its attendant ease of access and at reasonable cost. The finding shows that extension agents in the area use more than one ICTs devices in the dissemination of agricultural information and innovations in the area.

\section{Usefulness and Effectiveness of various ICTs Devices by Extension Agents}

The result of the distribution based on level of usefulness and effectiveness of various ICTs devices by extension agents is shown in Table 4. Using a discriminating index of $\geq 2.0$ for acceptance and $<2.0$ for rejection, the farmers reported a high, useful and acceptable level of 
effectiveness in ICTs devices which includes; radios, telephones (GSM), posters, printer, digital camera, digital projector, audio and video cassettes, films and slides, cinemas, digital projector and portable wireless amplifier.

The high, useful and acceptable level of effectiveness recorded in the above ICTs device in the area may be connected to the relatively high level of education on part of the farmers which boast language understanding, literacy clarity, avoidance of time wasting and mass outreach as outlined by Ephraim and Orikpe (2013).

Moreover, the use of films and slides and Internet services (e-mailing) for agricultural extension delivery in the area was reported not to be much useful and hence rejected. However, the poor use of films and slides and internet may be connected to poor electricity supply, poor connectivity and poor knowledge of internet use by farmers in the study area. The findings is strengthened by the studies of Purnomo and Lee (2010) who opined that the use of ICT facilities has continued to be hampered by the persistent problem of access, connectivity literacy, cost and epileptic power supply.

\section{Influence of Farmers Socio-economic Characteristics on their Level of Effectiveness in Use of ICTs Devices}

In order to determine the influence of farmers socio-economic characteristics on their level of effectiveness in use of ICTs devices as shown in Table 5, a multiple regression analysis was carried out in four functional forms (linear, semi-log, double-log and exponential forms). Based on the statistical significance of the coefficient and goodness of fit, the double-log function was chosen as lead equation. Age was found to be negatively related to level of effectiveness in use of ICTs devices by farmers but it is statistically significant at 5\% level of probability. This implies that younger farmers had high level of effectiveness in use of ICTs devices than their older counterparts. Education had a positive coefficient with the level of effectiveness in use of ICTs devices by farmers hence it is statistically significant at $1 \%$ level of probability. It is expected that the higher level of education will contribute significantly to understanding of the importance of ICTs use in agricultural extension delivery as well as enhance fast adoption of agricultural innovation by the farmers. Farming experience had a positive coefficient, hence, farmers with more years of experience would be more efficient, have better knowledge of agricultural innovations and are expected to run a more efficient and profitable enterprise.

Similarly, farm income, membership of farm association and access to extension agents had positive coefficient with the level of effectiveness and therefore, affects the use of ICT devices by farmers positively. Household size and marital status had a negative coefficient with the level of effectiveness.

\section{Farmers Barriers in Use of ICTs Devices in the area}

The result of the distribution based on farmers barriers in use of ICTs devices is presented in Table 6. It shows that about $94.00 \%, 86.00 \%$ and $78.00 \%$ of the farmers complained of high cost of ICTs devices, inadequate power supply and poor technical know-how respectively as Journal of the Faculty of Agriculture and Veterinary Medicine, Imo State University Owerri website: $w w w$ ajol.info 
the barriers they encounter in the use of ICTs devices in the area. High cost of ICTs devices such as smart phones and monthly internet subscription left most of the farmers unable to access some important information from extension agents through their email. Inadequate power supply made most of the farmers unable to use ICTs device when necessary as well as search for other source of power in order to charge and power their ICTs devices such as the smart phones.

Furthermore, poor network connectivity, high cost of purchasing ICTs and poor awareness to ICTs devices where identified by approximately $70.00 \%, 66.00 \%$ and $60.00 \%$ respectively as barriers in use ICTs devices by farmers in the area. There is no doubt that these problems are responsible for poor access and utilization of ICTs devices by farmers in the area, addressing these problems will not only be vital for effective extension delivery in the area but increasing farmers' standard of living.

\section{CONCLUSION}

Conclusively, farmers reported a high and an acceptable level of usefulness and effectiveness for radio $(X=3.80)$ among others. Estimated multiple regressions revealed that the socio-economic characteristic of the farmers had a significant influence on their level of effectiveness in use of ICTs devices in the area. The study confirmed the evidence that the use of ICTs devices in agricultural delivery is very useful and effective for farmers in the area. Therefore, the study recommends that; it is important to organize seminars and workshops for farmers on the use of various ICTs devices as this would enhance their use of ICT and promote effective agricultural extension delivery; better infrastructure, such as electricity as well as skill acquisition on the use of Information and Communication Technologies should be made available to farmers in the study area for maximum utilization of the potentials of Information and communication technologies. 


\section{REFERENCES}

Abdoulaye, T., A. S. Bamire, A. Oparinde, A. A. Akinola (2015).Determinants of Adoption of Improved Cassava Varieties among Farming Households in Oyo, Benue, and Akwa Ibom States of Nigeria; Harvest plus working paper; Pp:01-22

Bawa, D.B and A.O Ani (2014).Analysis of Adoption of Improved Maize Production Technology among Farmers in Southern Borno, Nigeria; Research on Humanities and Social Sciences; Vol .4,No.25;Pp:137-141

Dauda, S, Anonguku I and Kpamor, M.A. (2009) Problems associated with use of modern Information Communication Technology (ICT) for extension service delivery in Makurdi local government area. Proceedings of the 43rd annual conference of the Agricultural Society of Nigeria held in Abuja, 2009.

Ephraim A. O and Orikpe, G.O (2013). Information and Communication Technology and Enhancement of Agricultural Extension Services in the New Millennium; Journal of Educational and Social Research Vol. 3 (4); Pp; 155-159

Imo State Agricultural Development Program (Imo-ADP) (2013). Imo State Agricultural Project implementation completion review report. (accessed 28 February, 2016).Pp;1-54

Kudi, T. M., M. Bolaji, M.O Akinola and D.H Nasa (2011). Analysis of adoption of improved maize varieties among farmers in Kwara State, Nigeria; International Journal of Peace and Development Studies Vol. 1(3), pp. 8-12

Nigeria Population Commission (NPC) (2006). Nigeria Population Commission, Nigeria Federal Government Initiative of individual head count by gender. Spread, State by State, In: MOFINEWS; (accessed 28 February, 2016).Jan-Feb,2007, 6(3):Nigeria.

Nwachukwu, I. (2003). Agricultural Communication: Principles and Practice. Umuahia: Lamb House Publishers.

Ogunremi, J. B (2013). Assessment Of Extension Agents' Use Of Communication Methods And Its Impact On Aquaculture Linkage Activities In Lagos State, Nigeria; Journal of Agriculture and Social Research, Vol. 13, No.1,Pp:22-29

Olaniyi, O. A. (2013). Assessment Of Utilization Of Information And Communication Technologies (ICTs) Among Poultry Farmers In Nigeria: An Emerging Challenge; Transnational Journal of Science and Technology; vol.3, No.6; Pp: 29-43

Purnomo, S. H. and Lee, Y. (2010). An Assessment of Readiness and Barriers towards ICT Programme Implementation: Perceptions of Agricultural Extension Officers in Indonesia. International Journal of Educationand Development using Information and Communication Technology 6 (3): 19 - 36.

Salau, E. S. and Saingbe, N. D. (2008). Access and Utilization of Information and Communication Technologies (ICTs) Among Agricultural Researchers and Extension 
Workers in Selected Institutions in Nasarawa State of Nigeria, PAT: 4 (2): 1-11 Available online: www.patnsukjournal.com/currentissue

World Bank (2006). Global trends and policies. Washington: World Bank, Wikipedia, (2009) World Bank 200c. 
Table 1: Frequency distribution of socio-economic characteristics of respondents

\begin{tabular}{lll}
\hline Variable & Percentage $(\%)$ & Mean $(\mathbf{x})$ \\
\hline Age & & \\
$31-40$ & 18.00 & \\
$41-50$ & 52.00 & 45.00 years \\
$51-60$ & 24.00 & \\
$61-70$ & 6.00 &
\end{tabular}

Sex

Male

Female

26.00

\section{Level of Education}

No formal education

6.00

Primary education

26.00

Secondary education

64.00

12.00 years

Tertiary education

4.00

\section{Marital status}

Married

76.00

Single

18.00

Widowed

6.00

\section{Farming experience}

Less than 10

8.00

10-19

22.22

20.00 years

20-30

52.00

$31-40$

12.00

41 and above

6.00

\section{Household size}

1-5

32.00

6-10

68.00

6.0 persons

Member of farm association

Member

78.00

Non member

22.00

Journal of the Faculty of Agriculture and Veterinary Medicine, Imo State University Owerri website: www ajol.info 
Access to Extension agents

Access $\quad 42.00$

No access $\quad 58.00$

Average monthly farm income

Less than 20,000

$21,000-40,000 \quad 36.00$

$\begin{array}{lll}41,000-60,000 & 48.00 & \mathbf{N} 49,500.00\end{array}$

$61,000-80,000 \quad 10.00$

$81,000-100,000 \quad 2.00$

Source: Field survey, 2018

Table 2: Distribution of Farmers by Level of Awareness of ICTs devices used by Extension Agents

\begin{tabular}{lcc}
\hline Level of Awareness & Frequency & Percentage (\%) \\
\hline High & 41 & 82.00 \\
Moderate & 6 & 12.00 \\
Low & 3 & 6.00 \\
\hline Total & $\mathbf{5 0}$ & $\mathbf{1 0 0 . 0 0}$ \\
\hline
\end{tabular}

Source: Field Survey Data, 2018

Table 3: Distribution of the Types of ICTs Devices Used by Extension Agents

\begin{tabular}{lll}
\hline ICTs Devices & Frequency & Percentage $(\%)$ \\
\hline Radios & 50 & 100.0 \\
Telephones (GSM) & 48 & 96.00 \\
Posters & 43 & 86.00 \\
Printer & 40 & 80.00 \\
Digital camera & 38 & 76.00
\end{tabular}

Journal of the Faculty of Agriculture and Veterinary Medicine, Imo State University Owerri website: www ajol.info 


\begin{tabular}{lll} 
Television & 35 & 70.00 \\
Audio and video cassettes & 30 & 60.00 \\
Films and slides & 28 & 56.00 \\
Cinemas & 27 & 54.00 \\
Digital projector & 26 & 52.00 \\
Portable wireless amplifier & 23 & 46.00 \\
Internet services (e-mailing) & 20 & 40.00 \\
\hline
\end{tabular}

*Multiple Responses are recorded; Source: Field Survey Data, 2018

Table 4: Usefulness and Effectiveness of various ICTs Devices by Extension Agents

\begin{tabular}{|c|c|c|c|c|c|}
\hline ICTs Devices & $\begin{array}{l}\text { HE } \\
(3)\end{array}$ & ME (2) & $\mathbf{N}(\mathbf{1})$ & Mean & Remark \\
\hline Radios & 47 & 2 & 1 & 2.92 & Accepted \\
\hline Telephones (GSM) & 41 & 6 & 3 & 2.76 & Accepted \\
\hline Television & 13 & 32 & 5 & 2.10 & Accepted \\
\hline Posters & 43 & 5 & 2 & 2.82 & Accepted \\
\hline Printer s & 46 & 3 & 1 & 2.90 & Accepted \\
\hline Digital camera & 42 & 6 & 2 & 2.80 & Accepted \\
\hline Digital projector & 40 & 7 & 3 & 2.88 & Accepted \\
\hline Internet Services & 11 & 35 & 4 & 1.52 & Rejected \\
\hline Audio and video cassettes & 43 & 5 & 2 & 2.82 & Accepted \\
\hline Films and slides & 1 & 41 & 8 & 1.86 & Rejected \\
\hline Cinemas & 46 & 3 & 1 & 2.80 & Accepted \\
\hline Digital projector & 43 & 4 & 3 & 2.92 & Accepted \\
\hline Portable wireless amplifier & 40 & 7 & 3 & 2.74 & Accepted \\
\hline Grand Mean & 1368 & 257 & 65 & 2.60 & Accepted \\
\hline
\end{tabular}

Keys; HE: Highly Effective; ME; Moderately Effective: NE: Not effective, DI: Discriminating Index: 2.0 Accepted;

Field Survey Data, 2018

Journal of the Faculty of Agriculture and Veterinary Medicine, Imo State University Owerri website: www ajol.info 
Table 5: Estimated Regression Analysis of the Influence of Farmers Socio-economic Characteristics on their Level of Effectiveness in Use of ICTs Devices

\begin{tabular}{|c|c|c|c|c|}
\hline Explanatory variables & Linear & Semi-log & Double-log & Exponential \\
\hline \multirow[t]{2}{*}{ Constant } & 8.569 & 2.213 & 19.948 & 1.642 \\
\hline & $(5.379)^{* * *}$ & $(7.994)^{* * *}$ & $(8.088) * * *$ & $(8.327)^{* * *}$ \\
\hline \multirow[t]{2}{*}{ Age $\left(\mathrm{X}_{1}\right)$} & -0.005 & -0.001 & -1.080 & -0.000 \\
\hline & $(-0.460)$ & $(-0.377)$ & $(-2.414)^{* *}$ & $(-0.205)$ \\
\hline \multirow[t]{2}{*}{ Educational Level $\left(\mathrm{X}_{2}\right)$} & -0.001 & $-3.497 \mathrm{E}-005$ & 0.578 & $5.265 \mathrm{E}-013$ \\
\hline & $(-0.058)$ & $(-0.009)$ & $(3.361)^{* * *}$ & $(0.047)$ \\
\hline \multirow[t]{2}{*}{ Farming Experience $\left(\mathrm{X}_{3}\right)$} & 0.040 & 0.007 & 0.137 & $1.000 \mathrm{E}-013$ \\
\hline & $(0.801)$ & $(2.877)^{* * *}$ & $(2.170)^{* *}$ & $(1.844)^{*}$ \\
\hline \multirow[t]{2}{*}{ Household Size $\left(\mathrm{X}_{4}\right)$} & -0.080 & -0.016 & -0.958 & $-1.007 \mathrm{E}-013$ \\
\hline & $(-2.818) * * *$ & $(-3.149)^{* * *}$ & $(-1.595)^{*}$ & $(-2.689) * * *$ \\
\hline \multirow[t]{2}{*}{ Farm Income $\left(\mathrm{X}_{5}\right)$} & $2.887 \mathrm{E}-005$ & 5.365E-006 & 1.920 & 4.293E-006 \\
\hline & $(2.132)^{* *}$ & $(2.281)^{* *}$ & $(2.626) * * *$ & $(1.770)^{*}$ \\
\hline \multirow{2}{*}{$\begin{array}{l}\text { Membership of } \\
\text { Association }\left(\mathrm{X}_{6}\right)\end{array}$} & 0.048 & 0.008 & 0.668 & $-4.953 \mathrm{E}-005$ \\
\hline & $(0.448)$ & $(0.415)$ & $(4.143)^{* * *}$ & $(-0.309)$ \\
\hline \multirow{2}{*}{$\begin{array}{l}\text { Access to Extension Agents } \\
\left(\mathrm{X}_{7}\right)\end{array}$} & -0.009 & $-7.234 \mathrm{E}-005$ & 2.556 & 0.003 \\
\hline & $(0.092)$ & $(-0.004)$ & $(2.780)^{* * *}$ & $(0.196)$ \\
\hline \multirow[t]{2}{*}{ Marital Status $\left(\mathrm{X}_{8}\right)$} & -1.170 & -0.030 & -2.260 & $-1.939 \mathrm{E}-005$ \\
\hline & $(-1.614)^{*}$ & $(-1.659)^{*}$ & $(-2.332) * * *$ & $(-1.478)^{*}$ \\
\hline \multirow[t]{2}{*}{$\mathrm{R}^{2}$} & 75.9 & 83.0 & 89.1 & 81.5 \\
\hline & 74.4 & 80.1 & 87.1 & 80. \\
\hline \multicolumn{5}{|l|}{$\mathrm{R}^{2}{ }^{2}$} \\
\hline F-Ratio & $30.868 * * *$ & $32.281 * * *$ & $38.433 * * *$ & $23.700 * * *$ \\
\hline
\end{tabular}

Values in Parenthesis are t-values *Statistically Significant at $10 \%$; **Statistically Significant at 5\%; *** Statistically Significant at 1\%; Source: Field Survey (2018) 
Table 6: Distribution of Farmers Barriers in Use of ICTs Devices in the area

\begin{tabular}{lll}
\hline Barriers & Frequency & Percentage (\%) \\
\hline High cost of ICTs devices & 47 & 94.00 \\
Inadequate power supply & 43 & 86.00 \\
Poor technical know-how & 39 & 78.00 \\
Poor network connectivity & 35 & 70.00 \\
High cost of purchasing ICTs & 33 & 66.00 \\
Poor awareness to ICTs devices & 30 & 60.00 \\
\hline
\end{tabular}

*Multiple Responses are recorded; Source: Field Survey Data, 2018 